\title{
UJI SITOTOKSISITAS EKSTRAK DAUN MIMBA (Azadirachta indica) TERHADAP SEL FIBROBLAS BHK 21
}

\section{(SITOTOXICITY TEST OF NEEM LEAVES (Azadirachta indica) TOWARDS BHK-21 FIBROBLAST CELL)}

\author{
Qurni Restiani ${ }^{1}$, Mandojo Rukmo ${ }^{2}$ and Devi Eka Juniarti ${ }^{3}$ \\ ${ }^{1}$ Mahasiswa Pendidikan Dokter Gigi \\ ${ }^{2}$ Staf Pengajar Departemen Konservasi Gigi Kedokteran Gigi \\ Fakultas Kedokteran Gigi Universitas Airlangga \\ Surabaya-Indonesia
}

\begin{abstract}
Background: The leaves of neem (Azadirachta indicia) is one of herbal medicine that recommended as an alternative material of root canal irrigants. The active ingredients of neem leaves such as alkaloids, tannins, saponins and flavonoids has been proven to have antibacterial activity against E. faecalis. The ideal properties of an alternative material of root canal irrigants is not only have antibacterial activity but also is not toxic to the tissues, but the toxicity of neem leaves remains unclear until now. Objective: The aims of this study to determine the toxicity effect of neem leaves extract in specific concentration. Methods: This research was an experimental laboratory in vitro study of baby hamster kidney fibroblast (BHK-21). The neem leaves extract was made by maceration method using ethanol $96 \%$ and certain dilution performed to obtain various concentrations. Cytotoxicity test was conducted by MTT assay and the optical density was measured using ELISA reader at wavelength of $620 \mathrm{~nm}$. Then, the optical density values were calculated using the formula for determining the number of survival fibroblasts after tested. Results: The percentage of survival fibroblast at concentration of 50\%, 55\%, 60\%, 65\%, 70\%, 75\%, 80\%, 85\%, 90\%, 95, and $100 \%$ in sequence were $71.3 \%, 64,2 \%, 62 \%, 60.2 \%, 40.1 \%, 36.3 \%, 36.7 \%, 29 \%, 28.4 \%, 27.5 \%$, and $25.6 \%$. Conclusion: The extract of neem leaves (Azadirachta indica) has cytotoxic effects at concentration of $70 \%$ up to $100 \%$.
\end{abstract}

Keywords : Neem Leaves Extract, Citotoxicity, Fibroblast of BHK-21

Korespondensi (correspondence): 1. Qurni Restiani, Mahasiswa Pendidikan Dokter Gigi, Fakultas Kedokteran Gigi Universitas Airlangga. Jl. Prof. Moestopo 48, Surabaya. E-mail: qurnirestiani@ gmail.com

\section{PENDAHULUAN}

Perawatan saluran akar merupakan perawatan yang bertujuan untuk mengeliminasi keberadaan mikroba pada ruang pulpa dan saluran akar'. Perawatan saluran akar memiliki tiga prinsip dasar yang dikenal sebagai "Triad Endodontic" yang terdiri dari preparasi biomekanik, irigasi dan disinfeksi, serta obturasi ${ }^{2}$.

Larutan irigasi yang ideal memiliki efek antibakteri dengan spektrum yang luas, tidak toksik, mampu melarutkan sisa jaringan pulpa nekrotik, mencegah terbentuknya smear layer selama preparasi saluran akar atau mampu melarutkannya segera setelah terbentuk. Akan tetapi dari berbagai penelitian yang telah dilakukan, belum ada senyawa larutan irigasi yang dapat memenuhi kriteria yang ideal tersebut ${ }^{3}$.

Azadirachta indica atau yang dikenal sebagai mimba merupakan salah satu obat herbal yang memiliki banyak khasiat ${ }^{4}$. Tanaman mimba mengandung beberapa kandungan aktif yaitu alkaloid, tanin, saponin dan flavonoid yang memiliki daya antibakteri ${ }^{5}$.

Azadirachta indica dalam dunia kedokteran gigi telah banyak diteliti tentang daya antibakteri yang dimiliki untuk melawan 
mikroorganisme patogen endodontik seperti $S$. mutans, S. aureus dan E. faecalis ${ }^{6,7}$. Beberapa literatur juga menunjukkan bahwa daun mimba memiliki daya antimikroba dan efek terapetik yang berpotensi untuk digunakan sebagai larutan irigasi saluran akar ${ }^{8}$. Bagaimanapun juga, uji preklinis dan klinis perlu dilakukan terhadap suatu bahan sebagai syarat bahan perawatan saluran akar ${ }^{6}$. Uji toksisitas merupakan bagian awal dari evaluasi bahan kedokteran gigi sebelum digunakan pada manusia. Uji toksisitas dilakukan untuk mengetahui biokompatibilitas suatu bahan terhadap jaringan tubuh sebelum diaplikasikan langsung pada tubuh ${ }^{9}$.

Penelitian ini bertujuan untuk membuktikan toksisitas ekstrak daun mimba (Azadirachta indica) terhadap sel fibroblas BHK 21 pada konsentrasi tertentu.

\section{BAHAN DAN METODE}

Penelitian ini merupakan eksperimental laboratoris dengan menggunakan rancangan post test only control group design. Sampel dari penelitian ini yaitu ekstrak daun mimba (Azadirachta indica) yang dibuat di Balai Materia Medika Batu. Proses pembuatan dimulai dengan mencuci daun mimba dengan bersih lalu dianginanginkan, kemudian dikeringkan dengan oven dengan suhu $40^{\circ} \mathrm{C}$ sampai kering angin atau layu, diremas dan dihaluskan kemudian dimaserasi dengan larutan etanol 96\% dan diambil filtratnya dengan penyaringan. Hasil saringan diuapkan dalam rotatory vacum evaporation dengan suhu $40^{\circ} \mathrm{C}$. Pada akhir proses ini didapatkan ekstrak murni bebas etanol.

Sampel penelitian dibagi menjadi 13 kelompok, 11 kelompok mendapatkan perlakuan dan 2 kelompok sebagai kontrol sel dan kontrol media. Kelompok perlakuan terdiri dari kultur fibroblas yang diberi ekstrak daun mimba 50\%, 55\%, 60\%, $65 \%, 70 \%, 75 \%, 80 \%, 85 \%, 90 \%, 95 \%$, dan $100 \%$. Sampel kemudian diinkubasi selama 24 jam lalu ditambahkan MTT $10 \mu \mathrm{l}$ MTT dan inkubasi 3 jam pada $37^{\circ} \mathrm{C}$. Sel yang hidup akan bereaksi dengan MTT membentuk warna formazan biru, sedang yang mati tidak terbentuk warna biru. Selanjutnya formazan dibaca absorbansinya secara spetrofotometri dengan ELISA reader dengan panjang gelombang $620 \mathrm{~nm}$. Persentase kemampuan sel berproliferasi setelah perlakuan dihitung dengan rumus $\%$ kehidupan sel sebagai berikut:

$\%$ Kehidupan sel $=$ OD perlakuan + OD media $\times 100 \%$ OD kontrol sel + OD media
Keterangan:

$\%$ kehidupan sel : Persentase kehidupan sel setelah perlakuan

Perlakuan

: nilai OD (optical density) formazan setiap sampel setelah perlakuan

Media

: nilai OD (optical density) formazan setiap kontrol media

Sel

: nilai OD (optical density)

formazan pada setiap

kontrol sel

Data yang diperoleh ditabulasi kemudian dilakukan analisis statistik menggunakan uji normalitas Kolmogorov-Smirnov untuk mengetahui apakah data yang didapat berdistribusi normal, lalu dilanjutkan uji homogenitas varians menggunakan tes levene untuk menguji kesamaan varians dari beberapa sampel. Setelah diperoleh hasil dari uji normalitas dan homogenitas dilajutkan dengan analisis menggunakan uji parametrik atau uji non parametrik. Uji parametrik dilakukan jika data berdistribusi normal dan homogen yang selanjutnya dianalisis menggunakan one-way anova test, sedangkan jika data tidak memenuhi salah satu syarat tersebut maka uji selanjutnya yang digunakan adalah uji non parametrik dan menggunakan analisis dari Kruskal Wallis test. Pada penelitian ini nilai signifikansi ditentukan dengan menggunakan nilai $\mathrm{p}<0,05$.

\section{HASIL}

Berdasarkan hasil penelitian pada sel fibroblast BHK-21 setelah pemberian ekstrak daun mimba (Azadirachta indica), dilakukan pembacaan pada tiap-tiap kelompok perlakuan dan kontrol melalui metode MTT assay dengan ELISA reader dengan panjang gelombang 620 $\mathrm{nm}$. Terdapat 11 kelompok konsentrasi pengujian yaitu $50 \%, 55 \%, 60 \%, 65 \%, 70 \%, 75 \%, 80 \%$, $85 \%, 90 \%, 95 \%, 100 \%$, disertai dengan kontrol sel dan kontrol media dimana tiap kelompok perlakuan dilakukan 3 kali replikasi. Hasil pengujian pada tiap kelompok perlakuan adalah sebagai berikut :

Tabel 1. Hasil rata-rata optical density ekstrak daun mimba, standar deviasi, dan persentase kehidupan sel. 


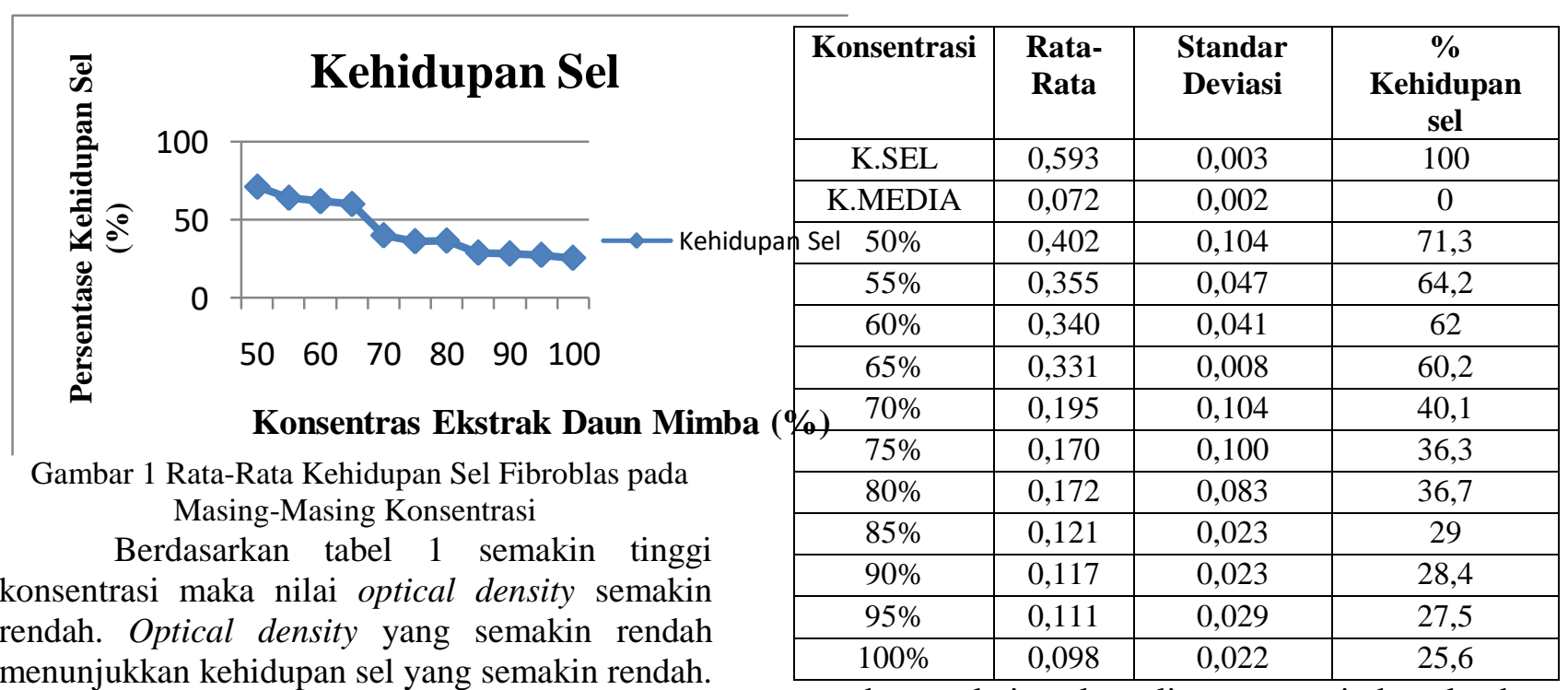
menunjukkan kehidupan sel yang semakin rendah. Dari data diatas, persentase kehidupan sel terbesar berada pada konsentrasi 50\% yaitu sebesar 71,3\% sedangkan persentase kehidupan sel yang paling rendah berada pada konsentrasi $100 \%$ yaitu sebesar 25,6\%. Untuk mengetahui perbedaan signifikan antar kelompok perlakuan maka perlu dilakukan analisa data.

Pada data hasil pengukuran optical density menggunakan Elisa reader, dilakukan uji normalitas menggunakan uji KolmogorovSmirnov untuk melihat apakah data yang didapat berdistribusi normal. Data dikatakan berdistribusi normal apabila $\mathrm{p}>0,05$. Pada masing-masing kelompok perlakuan diperoleh nilai $p>0,05$ yang berarti data yang didapatkan berdistribusi normal. Levene test dilakukan untuk mengetahui homogenitas data sebagai syarat uji signifikansi menggunakan ANOVA. Diperoleh hasil $\mathrm{p}=0,007$ $(\mathrm{p}<0,05)$ yang menunjukkan data bersifat tidak homogen. Oleh karena itu, uji signifikansi dilakukan menggunakan uji non parametrik melalui analisis Kruskall Wallis test dan didapatkan $\mathrm{p}=0,007(\mathrm{p}<0,05)$ yang menunjukkan adanya perbedaan yang signifikan pada seluruh kelompok perlakuan.

\section{PEMBAHASAN}

Penelitian ini merupakan penelitian eksperimental laboratoris untuk mengetahui toksisitas ekstrak daun mimba (Azadirachta indica) pada konsentrasi tertentu. Pada penelitian ini dilakukan uji sitotoksisitas ekstrak daun mimba dengan MTT assay pada konsentrasi 50\%, $55 \%, 60 \%, 65 \%, 70 \%, 75 \%, 80 \%, 85 \%, 90 \%$, 95\%, dan 100\% terhadap sel fibroblas BHK 21. Penggunaan kultur sel BHK-21 yang diberasal dari fibroblas ginjal hamster dikarenakan sel fibroblas merupakan sel terpenting dan komponen

terbesar dari pulpa, ligamen periodontal, dan gingival $^{9}$. Data hasil penelitian dilakukan uji statistik dan didapatkan data berdistribusi normal, sedangkan untuk uji homogenitas dari hasil penelitian menunjukkan variasi data yang tidak homogen, sehingga analisis statistik selanjutnya dilakukan dengan uji non parametrik melalui uji Kruskal Wallis dan didapatkan bahwa terdapat perbedaan yang signifikan jumlah sel yang hidup dari seluruh kelompok perlakuan.

Berdasarkan hasil penelitian didapatkan nilai absorbansi yang semakin menurun dengan meningkatnya konsentrasi ekstrak daun mimba, hal ini menandakan terjadinya penurunan jumlah sel yang hidup seiring dengan peningkatan konsentrasi ekstrak daun mimba. Pada konsentrasi $50 \%, 55 \%, 60 \%$, dan $65 \%$ didapatkan sel yang hidup masih mencapai lebih dari 50\% sehingga dapat dikatakan pada konsentrasi tersebut ekstrak daun mimba bersifat tidak toksik. Namun pada konsentrasi $70 \%, 75 \%, 80 \%, 85 \%, 90 \%, 95 \%$, dan $100 \%$ jumlah sel yang hidup kurang dari $50 \%$ sehingga pada konsentrasi ini ekstrak daun mimba dapat dikatakan memiliki sifat yang toksik. Suatu bahan dikatakan toksik apabila jumlah sel yang hidup setelah terpapar bahan tersebut kurang dari $50 \%^{10}$. Hal ini kemungkinan disebabkan oleh komponen-komponen dari ekstrak daun mimba yang dapat menyebabkan kematian dari sel fibroblas BHK-21. Adapun kandungan dari ekstrak daun mimba yang diduga menyebabkan kematian sel fibroblas yaitu antara lain azadirakhtin, saponin, alkaloid, dan tanin.

Pada uji fitokimia pada Balai Penelitian dan Konsultasi Laboratorium (BPKI) Surabaya didapatkan kandungan azadirachtin sebesar $2,38 \%$. Azadirakhtin merupakan senyawa aktif yang terkandung pada ekstrak daun mimba yang 
dapat Azadrakhtin pada kultur sel fibroblas dapat menyebabkan terjadinya penurunan laju respirasi sel. Hal ini dikarenakan azadirakhtin dapat mempengaruhi sisi aktif pada mitokondria yang berfungsi mengikat oksigen sehingga dapat menggangu proses transport elektron pada saat respirasi berlangsung. Proses respirasi yang terhambat dapat menyebabkan penurunan energi yang dihasilkan sehingga dapat mengganggu pembentukan protein dan asam nukleat ${ }^{11}$.

Zat aktif saponin yang terkandung dalam ekstrak daum mimba juga cukup tinggi yaitu $2,11 \%$. Saponin merupakan senyawa yang memiliki sifat toksisitas yang cukup kuat ${ }^{12,13}$. Hal ini dikaitkan dengan struktur saponin yang mengandung molekul ampifatik (mengandung regio hidrofilik dan hidrofobik) yang dapat melarutkan protein membran. Ujung hidrofobik saponin berikatan pada regio hidrofobik protein membran sel dengan menggeser sebagian besar unsur lipid yang terikat. Ujung hidrofilik saponin merupakan ujung yang bebas akan membawa protein ke dalam larutan sebagai kompleks deterjen-protein. Akibatnya membran sel akan pecah dan mengalami lisis. Membran sel memiliki peran yang sangat penting, berfungsi melindungi dan mempertahankan isi sel, serta mengatur lalu lintas molekul-molekul yang berguna dalam mempertahankan kehidupan sel ${ }^{14}$.

Alkaloid merupakan salah satu kandungan kimia dari daun mimba yang cukup tinggi yaitu $3,01 \%$. Alkaloid dapat bekerja spesifik pada siklus sel dengan menghambat proses mitosis. Hambatan pembelahan sel yang terjadi akibat senyawa alkaloid terjadi pada stadium metafase sehingga proses proliferasi sel menjadi terhambat ${ }^{15}$. Golongan alkaloid juga dapat menyebabkan ikatan terhadap tubulin yaitu suatu protein yang menyusun mikrotubulus dengan menghambat atau memblokade polimerisasi protein ke dalam mikrotubulus. Hal ini akan menyebabkan terganggunya fungsi mikrotubulus sebagai sitoskleton atau penyusun kerangka sel sehingga bentuk sel menjadi tidak beraturan dan menyebabkan ganguan transport zat keluar ke dalam sel ${ }^{16}$.

Zat aktif tanin yang juga terkandung pada ekstrak daun mimba juga berperan dalam menyebabkan kematian pada sel fibroblas. Tanin merupakan senyawa golongan fenolik yang memiliki kepolaran tinggi. Ikatan antara senyawa polar dengan lipoprotein sel menyebabkan terjadinya penimbunan senyawa disertai pemecahan lemak yang mengganggu permeabilias sel fibroblas yang menyebabkan sel bengkak dan pecah $^{17}$.

Setelah dilakukan analisis statistik menggunakan uji Kruskal Wallis, dilakukan pula analisis statistik lanjutan berupa Post-Hoc Comparison test menggunakan metode Tukey $H S D$ untuk mengetahui konsentrasi dari ekstrak daun mimba yang memiliki toksisitas paling tinggi. Pada uji tersebut menunjukkan bahwa perlakuan dengan ekstrak daun mimba konsentrasi $70 \%$ sampai $100 \%$ menunjukkan perbedaan yang tidak bermakna. Oleh karena itu, berdasarkan hasil uji diatas dapat dikatakan pula bahwa ekstrak daun mimba diantara konsentrasi $70 \%$ hingga $100 \%$ memiliki efek toksisitas yang sama terhadap sel fibroblas BHK-21. Hal tersebut dimungkinkan karena ekstrak daun mimba pada konsentrasi diantara $70 \%$ hingga $100 \%$ mampu menyebabkan gangguan pada sel fibroblas sehingga menyebabkan kematian sel lebih dari $50 \%$. Hal tersebut sesuai dengan penelitian yang telah dilakukan oleh Roma et al. yang menyatakan bahwa pada konsentrasi yang lebih tinggi ekstrak daun mimba mampu menyebabkan terjadinya kerusakan pada mitokondria sel yang disebabkan oleh stress oksidatif ${ }^{18}$. Stress oksidatif yang dihasilkan ekstrak daun mimba mampu menyebabkan perubahan pada permeabilitas dari membran mitokondria yang selanjutnya menginisiasi aktivasi dari protein pro-apoptosis (Bax protein). Insisiasi dari protein pro-apotosisi mampu menyebabkan pengeluaran sitokrom $\mathrm{c}$ pada sitoplasma sel yang dapat menyebabkan fragmentasi DNA sehingga memicu kematian $\operatorname{sel}^{18,19}$. Oleh karena itu penggunaan ekstrak daun mimba perlu diperhatikan agar mendapatkan efek terapeutik dan terhindar dari efek sitotoksik.

\section{DAFTAR PUSTAKA}

1. Ercan E, Ozekinci T, Atakul F, Gül K. 2004. Antibacterial activity of $2 \%$ chlorhexidine gluconate and 5.25\% sodium hypochlorite in infected root canal: In vivo study. J Endod 30:84-7

2. Shahani \& Reddy S 2011. Comparison of antimicrobial substantivity of root canal irrigants in instrumented root canals up to $72 \mathrm{~h}$ : an in vitro study. Journal of the Indian Society of Pedodontics \& Preventive Dentistry; 29:28-33

3. Naenni, K. Thoma, and M. Zehnder.2004.Soft tissue dissolution capacity of currently used and potential 
endodontic irrigants.Journal of Endodontics, 30(11): 785-787

4. Farkhan A, Arijani E, Yuliati. 2012. Toksisitas Kandungan Tanin dan Sapoin pada Ekstrak Daun Mimba (Azadirachta indica) dengan Menggunakan Metode MTT Assay.

5. Lekshmi, NJCP, Sowmia N, Viveka S, Brindha R, Jeeva S 2012. The inhibiting effect of Azadirachta indica against dental pathogens. Pelagia Research Library, Asian Journal of Plants Science and Research, 2 (1): 6-10, p. 9

6. Mistry KS, Sanghvi Z, Parmer G, Shah S, 2014. The antimicrobial activity of Azadirachta indica, Mimusops elengi, Tinospora cardifolia, Ocimum sanctum dan $2 \%$ chlorhexidine gluconate on common endodontic pathogens: An in vitro study, European Journal of Dentistry 8(2):172-177

7. Botelho $\mathrm{M}$, Araujo DS, Martins J, Carvalho C, Paz M, Azenha C, Ruela R, Queiroz D, Ruela W, Marino G,Ruela F.2008. Efficacy of a mouthrinse based on leaves of neem in the treatment of patients with chronic gingivitis. J Medicinal Plants Research. 2(11): 341-346

8. Kausik B, Ishita C, Ranajit K. Banerjee and Uday B.2002.Biological activities and medicinal properties of neem (Azadirachta indica) Current Science. 82(11): 1336-1345

9. Yuliati, Anita 2005. Viabilitas sel fibroblas BHK-21 pada permukaan resin akrilik rapid heat cured. Majalah Kedokteran Gigi. (Dent. J.), 38(2):68-72

10. Khoswanto C, Arijani E, Soesilawati P. 2008. Cytotoxicity test of 40, 50 and $60 \%$ citric acid as dentin conditioner by using MTT assay on culture cell line. Majalah Kedokteran Gigi 41(3)

11. Salehzadeh A \& Abbasalipour. 2003. The Comparison of Rotenone and Environmentally Safe Insecticide (Azadirachtin) on Culture Cell Respiration. J Rsh Health Sci 3(2):1-8
12. Akinpelu B,Igbeneghu O, Awotunde A, Iwalewa E, Oyedapo O. 2014. Antioxidant and Antibacterial Activities of Saponin Fractions of Erythropeleum suaveolens (Guill. And Perri.) Stem Bark Extract. Academic Journals:University of Ibadan. 9(18)

13. Podolak I, Galanty A, Sobolewska D. Saponins as cytotoxic agents: a review. Phytochemistry Reviews. 2010;9(3):425-474.

14. Renawati, Enggiana. 2011. Sitotoksisitas Ekstrak Etanol Aloe vera Terhadap Sel Fibroblas Sebagai Bahan Medikamen Saluran Akar Secara In Vitro.[Skripsi]. Medan:Universitas Sumatra Utara.

15. Adyana, I.D.P. 2006. Efek Anti Telomerase Fraksi Alkaloid Terhadap Pembelahan dan Mitosis Sel Mieloma Mencit. Fakultas Kedokteran Hewan Universitas Airlangga.

16. Chabner, B.A., D.P.Rian, L.Paz-Ares, R.G. Carbonero, and P. Calabresi. 2001. Antineoplastic Agents In Goodman \& Gilman's The Pharmacological Basis of Therapeutics 10th. Edition. McGraw-Hill. Medical Publishing Division. P.14171421

17. Yunus, Renna. 2012. Uji Sitotoksisitas Ekstrak Buah Mahkota Dewa (Phaleria macrocarpa S.). [Skripsi]. Surabaya:Universitas Airlangga.

18. Roma A, Ovadje P, Steckle M, Nicoletti L, Saleem A, Pandey S. 2015. Selective Induction of Apoptosis by Azadarichta indica Leaf Extract by Targeting Oxidative Vulnerabilities in Human Cancer Cells. J Pharm Pharm Sci.18(4):729 - 746

19. Chaube SK, Shrivastav TG, Tiwari M, Prasad S, Tripathi A, Pandey AK. 2014. Neem (Azadirachta indica L.) leaf extract deteriorates oocyte quality by inducing ROS-mediated apoptosis in mammals. Varanasi : Hindu University 3(464) 